CZASOPISMO INŻYNIERII LADOWEJ, ŚRODOWISKA I ARCHITEKTURY JOURNAL OF CIVIL ENGINEERING, ENVIRONMENT AND ARCHITECTURE

JCEEA, t. XXXIII, z. 63 (2/I/16), kwiecień-czerwiec 2016, s. 179-189

\author{
Anna MUSZ-POMORSKA ${ }^{1}$ \\ Małgorzata IWANEK ${ }^{2}$ \\ Pawel SUCHORAB ${ }^{3}$ \\ Agnieszka BRODACZEWSKA ${ }^{4}$
}

\title{
ANALIZA STRAT WODY NA PRZYKŁADZIE WYBRANEGO WODOCIĄGU GRUPOWEGO
}

\begin{abstract}
Celem niniejszego artykułu jest analiza pracy wybranego wodociągu grupowego w latach 2003-2012 w aspekcie strat wody. Badany wodociąg zasilany jest z czerech ujęć zlokalizowanych w sąsiadujących z sobą miejscowościach. Łączna długość sieci wraz z przyłączami wynosi $489 \mathrm{~km}$. Przewody wykonane są głównie z polichlorku winylu oraz polietylenu dużej gęstości. Obciążenie poszczególnych stref jest nierównomierne i waha się od $5,63 \mathrm{~m}^{3} /(\mathrm{d} \cdot \mathrm{km})$ w strefie $\mathrm{B}$ do $16,45 \mathrm{~m}^{3} /(\mathrm{d} \cdot \mathrm{km})$ w strefie A. Średnia produkcja wody w latach 2003-2012 wynosiła $598794,2 \mathrm{~m}^{3} /$ rok. W pracy zastosowano standardowe metody badawcze - bilansowanie według International Water Association oraz metodę wskaźnikową. Wyznaczono procentowy wskaźnik strat wody $(S)$, jednostkową objętość strat przypadającą na jednego mieszkańca $\left(q_{S T R}\right)$, jednostkowy wskaźnik strat wody $\left(q_{s j}\right)$, wskaźnik jednostkowych strat rzeczywistych, przy co najmniej 20 przyłączach przypadających na $1 \mathrm{~km}$ sieci $(R L B)$, wskaźnik przecieków infrastruktury (ILI) oraz wskaźnik objętości wody niedochodowej $(N R W B)$. Badania przeprowadzono na podstawie danych uzyskanych z przedsiębiorstwa wodociągowego. Najwyższą wartość większości wskaźników strat wody zaobserwowano w 2005 roku, później nastąpił spadek ich wartości i w 2010 roku ponowny wzrost. Niska wartość ILI, we wszystkich strefach poniżej 1,5 , świadczy o bardzo dobrym stanie technicznym sieci. Najwyższe straty wody zaobserwowano w strefie zasilanej z ujęcia B. Również dla tej strefy wartość wskaźnika $R L B$ i $N R W B$ jest najwyższa. Wyznaczone wskaźniki start wody są porównywalne do opublikowanych wartości, uzyskanych dla innych systemów wodociągowych i wskazują na zadowalający stan badanej sieci.
\end{abstract}

Słowa kluczowe: wskaźniki strat wody, bilans wody, metody IWA

\footnotetext{
${ }^{1}$ Autor do korespondencji/corresponding author: Anna Musz-Pomorska, Politechnika Lubelska, Wydział Inżynierii Środowiska, ul. Nadbystrzycka 40 B, 20-618 Lublin, tel. (81)5384481, e-mail: A.Musz@wis.pol.lublin.pl

2 Małgorzata Iwanek, Politechnika Lubelska

${ }^{3}$ Paweł Suchorab, Politechnika Lubelska

${ }^{4}$ Agnieszka Brodaczewska, absolwentka Politechniki Lubelskiej
} 


\section{Wprowadzenie}

Problem strat wody dotyczy niemal wszystkich wodociągów na świecie. Straty te stanowią niekiedy bardzo duży procent objętości wody wtłaczanej do sieci. W Polsce problem strat wody mocno uwidocznił się po zmianach ustrojowych i wprowadzeniu gospodarki rynkowej, która wymusiła na przedsiębiorstwach wodociągowych podejmowanie działań zmierzających do ograniczenia nadmiernych strat wody. Straty wody definiowane jako różnica pomiędzy zmierzoną objętością wody wtłoczonej do sieci a zafakturowaną wielkością wody dostarczonej odbiorcom dzielą się na rzeczywiste i pozorne. Wielkość strat, niezależnie od ich rodzaju, wpływa na jakość i koszt wody dostarczanej odbiorcom [17], a także oddziałuje na kondycję finansową przedsiębiorstw wodociągowych $[11,15,17,19,20]$.

Straty wody są jednym z podstawowych elementów oceny stanu technicznego systemu wodociągowego. Analiza tych strat powinna być zatem podstawą do podejmowania działań modernizacyjnych i naprawczych, a tym samym zmniejszenia kosztów związanych z produkcją i dystrybucją wody. International Water Association (IWA) proponuje cztery metody działań [8]: aktywną kontrolę wycieków, szybkość i jakość napraw, kontrolę i regulację ciśnienia oraz konserwację, odnowę i wymianę przewodów w celu ograniczenia wielkości start wody. Ważnym elementem działań zmierzających do ograniczenia strat jest również ciągły monitoring pracy sieci wspomagany systemami informatycznymi [5], a także utrzymywanie ciśnienia w sieci na minimalnym wystarczającym poziomie [7].

Celem niniejszego artykułu jest analiza strat wody w wybranym wodociągu grupowym. W pracy wykorzystano standardowe metody badawcze (bilansowanie według International Water Association oraz metodę wskaźnikową). Analizie poddano straty wody $\mathrm{w}$ całym rozpatrywanym systemie dystrybucji $\mathrm{w}$ latach 2003-2012. Ponadto, ze względu na stosunkowo duże zróżnicowanie stref zasilania wodociągu grupowego, przeprowadzono analizę produkcji, zużycia i strat wody w roku 2012 dla każdej strefy oddzielnie.

\section{Charakterystyka systemu dystrybucji}

Badania strat wody przeprowadzono dla wybranego wodociągu grupowego znajdującego się w województwie lubelskim. Badany wodociąg zasilany jest z czterech ujęć zlokalizowanych w sąsiadujących z sobą miejscowościach. Główne przewody, o łącznej długości ok. $254 \mathrm{~km}$, wykonane są w większości z rur z polichlorku winylu (PVC-U) oraz polietylenu dużej gęstości (PE-HD). Łączna długość przyłączy wynosi ok. $235 \mathrm{~km}$. Średnie zużycie wody przypadające na jednego mieszkańca w roku 2012 wynosiło $82 \mathrm{dm} 3 / \mathrm{d}$. Charakterystykę sieci z podziałem na strefy zasilania przedstawiono $\mathrm{w}$ tabeli 1 . Uwagę zwraca duża nierównomierność obciążenia stref wodociągu zasilanych z poszczególnych ujęć - w strefie zasilanej $\mathrm{z}$ ujęcia A jest ono 2,9 razy większe niż w strefie zasilanej z ujęcia B. 
Tabela 1. Charakterystyka sieci wodociągowej z podziałem na strefy zasilania

Table 1. Characteristics of water supply zones

\begin{tabular}{|l|c|c|c|c|}
\hline \multicolumn{1}{|c|}{ Lokalizacja ujęcia } & A & B & C & D \\
\hline Długość sieci [km] & 16,47 & 102,6 & 48,02 & 87,24 \\
\hline Liczba przyłączy [szt.] & 600 & 1555 & 737 & 2209 \\
\hline Długość przyłączy [km] & 16 & 90,58 & 43,39 & 86 \\
\hline Liczba mieszkańców w roku 2012 & 2204 & 3904 & 2717 & 8423 \\
\hline Średnie ciśnienie w strefie [MPa] & 0,35 & 0,38 & 0,37 & 0,35 \\
\hline Zużycie wody na potrzeby własne [m³/rok] & 450 & 500 & 2050 & 8060 \\
\hline $\begin{array}{l}\text { Wsp. intensywności obciążenia sieci w ro- } \\
\text { ku 2012 [m³/(d·km)] }\end{array}$ & 16,45 & 5,63 & 5,68 & 9,17 \\
\hline
\end{tabular}

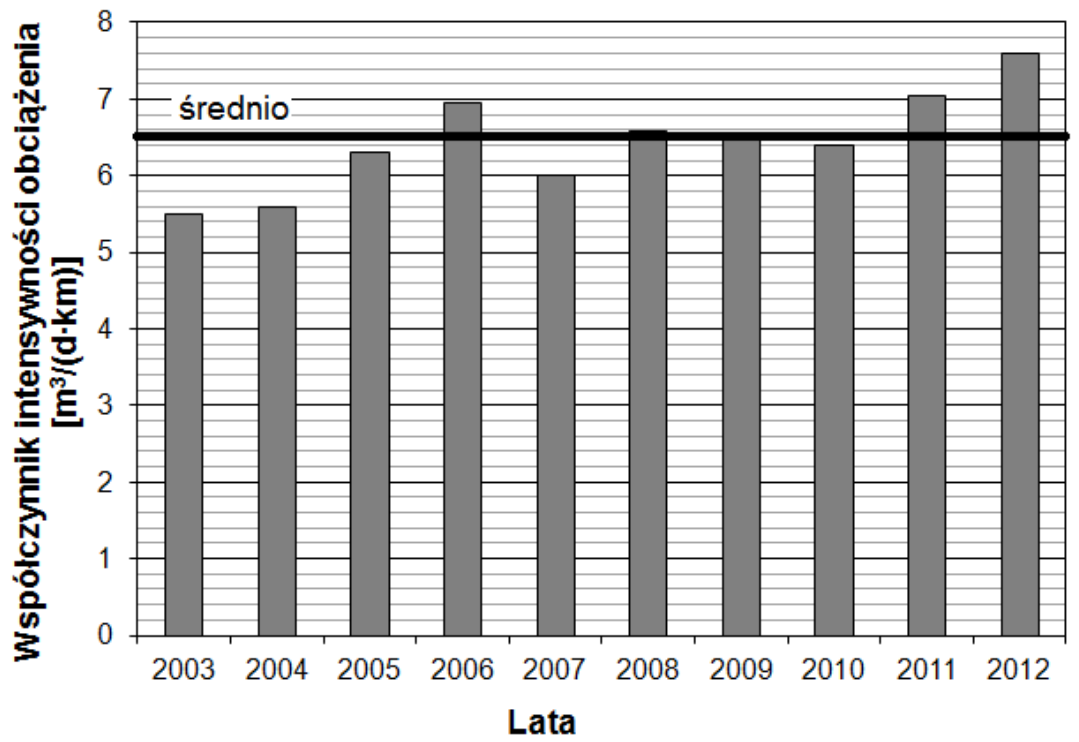

Rys. 1.Wartość współczynnika intensywności obciążenia sieci wodociągowej w latach 2003-2012

Fig. 1. Water intensity indicator values of the water supply network in years 2003-2012

Współczynnik intensywności obciążenia poszczególnych stref zasilania sieci wodociągowej wyznaczono zgodnie z zależnością podaną przez Dohnalika i Jędrzejewskiego [7]:

$$
O_{S}=\frac{V_{D S}}{365 \cdot L}
$$

gdzie: $O_{S}-$ współczynnik intensywności obciążenia danej strefy $\left[\mathrm{m}^{3} /(\mathrm{d} \cdot \mathrm{km})\right]$,

$V_{D S}$ - objętość wody dostarczonej do danej strefy zasilania $\left[\mathrm{m}^{3} / \mathrm{r}\right]$,

$L$-długość sieci magistralnej i rozdzielczej w obrębie strefy zasilania $[\mathrm{km}]$. 
Współczynnik intensywności obciążenia całej analizowanej sieci wodociągowej w latach 2003-2012 (Rys. 1) obliczony został jako średnia ważona wartości wyznaczonych według wzoru (1) dla każdej ze stref zasilania (wagą jest długość sieci). Średnia arytmetyczna wartości tego parametru dla sieci w rozpatrywanym okresie wyniosła $6,5 \mathrm{~m}^{3} /(\mathrm{d} \cdot \mathrm{km})$.

W latach 2003 - 2012 wyprodukowano średnio 598794,2 $\mathrm{m}^{3} /$ rok wody, przy czym najmniej - $509000 \mathrm{~m}^{3} /$ rok w roku 2003, najwięcej - $701040 \mathrm{~m}^{3} /$ rok w 2012. Biorąc pod uwagę poszczególne strefy zasilania, największy udział w produkcji wody miała strefa D $\left(270401,5 \mathrm{~m}^{3} /\right.$ rok $)$, najmniejszy zaś C $\left(78713 \mathrm{~m}^{3} / \mathrm{rok}\right)$. $\mathrm{W}$ strefie $\mathrm{B}\left(162457 \mathrm{~m}^{3} / \mathrm{rok}\right)$ produkcja wody była 2 razy większa, zaś w strefie $\mathrm{A}\left(87222 \mathrm{~m}^{3} / \mathrm{rok}\right) 1,1$ razy większa niż w strefie zasilanej z ujęcia $\mathrm{C}$.

W analizowanym okresie ilość wody sprzedanej miała tendencję wzrostową. Średnia sprzedaż wody w latach 2003 - 2012 wynosiła $468606 \mathrm{~m}^{3} /$ rok. Najwyższa sprzedaż wystąpiła w roku 2012 i była o $10 \%$ większa od wartości średniej dla analizowanego okresu. Natomiast najniższa sprzedaż wystąpiła w 2003 roku i była o $20 \%$ mniejsza od wartości średniej. Sprzedaż wody odbiorcom indywidualnym i gospodarstwom rolnym w analizowanym okresie wynosi ponad $90 \%$ w stosunku do całej objętości wody sprzedanej. Dużo mniejszy udział stanowi objętość wody sprzedanej odbiorcom związanym z działalnością gospodarczą i oświatową ('średnio 5\%) oraz sprzedaż hurtowa (średnio 3\%).

\section{Metodyka badań}

Analizę strat wody przeprowadzono przy zastosowaniu dwóch metod badawczych: bilansowej według International Water Association (IWA) oraz metody wskaźnikowej. W analizach uwzględniono straty wody w latach 2003-2012 w całej sieci bez podziału na strefy zasilania oraz w roku 2012 dla poszczególnych stref. Uzyskane wyniki obliczeń porównano z danymi literaturowymi podawanymi dla systemów wodociągowych o zbliżonej wartości współczynnika intensywności obciążenia sieci.

\subsection{Składniki bilansu wody według IWA}

Zgodnie z metodyką bilansu zalecaną przez IWA wodę wtłoczoną do sieci dystrybucyjnej podzielono na dwie podstawowe grupy: wodę zużytą na autoryzowaną konsumpcję oraz straty wody. Następnie autoryzowaną konsumpcję podzielono na zafakturowaną autoryzowaną konsumpcję, czyli ilość wody sprzedanej oraz niezafakturowaną autoryzowaną konsumpcję, czyli ilość wody zużytej na potrzeby własne przedsiębiorstwa. Wśród strat wody wyróżniono rzeczywiste i pozorne. Straty wody i niezafakturowana autoryzowana konsumpcja stanowią wodę nieprzynoszącą dochodu $[1,9,18]$. Szczegółowe informacje odnośnie zastosowanej metody można znaleźć w pracach np. $[11,18,19]$. Bilans wody w sieci wodociągowej według standardu IWA jest metodą szacunkową, ponieważ nie wszystkie dane potrzebne do sporządzenia bilansu można dokładnie określić. 
Na podstawie danych literaturowych, w badaniach przyjęto, że błędy pomiarów i odczytów wodomierzy stanowią $3 \%$ objętości wody wtłoczonej do sieci, a nieautoryzowana konsumpcja - $2 \%$ [1,2,14]. Zgodnie z informacjami uzyskanymi w lokalnym przedsiębiorstwie wodociągowym przyjęto również, że zafakturowana niezmierzona konsumpcja oraz straty na zbiornikach magazynujących wodę wynoszą $0 \mathrm{~m}^{3} /$ rok.

\subsection{Analiza wskaźnikowa strat wody w latach 2003-2012}

W zastosowanej analizie wskaźnikowej wyznaczono grupę wskaźników, których wyniki pozwoliły na ocenę prawidłowości i celowości podejmowanych działań eksploatacyjnych, a także dały możliwość porównania strat w całym systemie. W ramach analiz wyznaczono: procentowy wskaźnik strat wody $(S)$, jednostkową objętość strat przypadającą na jednego mieszkańca $\left(q_{S T R}\right)$, jednostkowy wskaźnik strat wody $\left(q_{s j}\right)$, wskaźnik jednostkowych strat rzeczywistych przy co najmniej 20 przyłączach przypadających na $1 \mathrm{~km}$ sieci $(R L B)$, wskaźnik przecieków infrastruktury (ILI) oraz wskaźnik objętości wody niedochodowej $(N R W B)$. Porównanie uzyskanych wskaźników z wartościami krytycznymi oraz z opublikowanymi wartościami wskaźników dla podobnych wodociągów umożliwiło ocenę stanu eksploatacyjnego rozpatrywanego systemu.

\section{Bilans i analiza strat wody $w$ wodociągu $w$ latach 2003-2012}

Wybrane składniki wykonanych bilansów wody dla całej rozpatrywanej sieci wodociągowej dla lat 2003-2012 przedstawiono w tabeli 2. Wykonanie bilansów umożliwiło wyznaczenie wartości wskaźników strat wody dla okresu 2003-2012 (Tabela 3). Z przeprowadzonych bilansów strat wody metodą IWA

Tabela 2. Składniki bilansu wody według IWA dla lat $2003-2012$

Table 2. Components of water balance according to IWA in $2003-2012$

\begin{tabular}{|c|c|c|c|c|c|}
\hline \multirow{2}{*}{$\begin{array}{c}\text { Rok } \\
\text { analizy }\end{array}$} & \multicolumn{5}{|c|}{\begin{tabular}{|c|} 
Składniki bilansu $\left[\mathrm{m}^{3} / \mathbf{r}\right]$ \\
\end{tabular}} \\
\hline & $\begin{array}{c}\text { Woda wtło- } \\
\text { czona do sieci }\end{array}$ & $\begin{array}{c}\text { Zafakturowana } \\
\text { aut. kons. }\end{array}$ & $\begin{array}{c}\text { Niezafakturowa- } \\
\text { na aut. kons. }\end{array}$ & $\begin{array}{c}\text { Straty wody } \\
\text { pozorne }\end{array}$ & $\begin{array}{l}\text { Straty wody } \\
\text { rzeczywiste }\end{array}$ \\
\hline 2003 & 509000 & \begin{tabular}{|l|l}
389969 & \\
\end{tabular} & 16410 & 25450 & 77171 \\
\hline 2004 & 522410 & 395038 & 16410 & 26121 & 84842 \\
\hline 2005 & 587210 & 415562 & 16410 & 29361 & 125878 \\
\hline 2006 & 642500 & 478463 & 16410 & 32125 & 115502 \\
\hline 2007 & 557667 & 482850 & 16410 & 27883 & 30524 \\
\hline 2008 & 613210 & 494557 & 16410 & 30661 & 71583 \\
\hline 2009 & 608170 & 506592 & 16410 & 30409 & 54760 \\
\hline 2010 & 593315 & 517873 & 16410 & 29666 & 29366 \\
\hline 2011 & 653420 & 484404 & 16410 & 32671 & 119935 \\
\hline 2012 & 701040 & 520755 & 16410 & 35052 & 128823 \\
\hline
\end{tabular}


Tabela 3. Wskaźniki strat wody dla okresu 2003-2012

Table 3. Indicators of water losses in 2003-2012

\begin{tabular}{|c|c|c|c|c|c|c|}
\hline \multirow{3}{*}{ Rok analizy } & \multicolumn{6}{|c|}{ Wskaźnik } \\
\hline & $S$ & $q_{S T R}$ & $q_{s j}$ & $R L B$ & $I L I$ & $N R W B$ \\
\hline & $\%$ & $\mathrm{dm}^{3} /(\mathrm{os} \cdot \mathrm{d})$ & $\mathrm{m}^{3} /(\mathbf{h} \cdot \mathbf{k m})$ & $\mathrm{dm}^{3} /($ szt. przył. d $)$ & - & $\%$ \\
\hline 2003 & 20,2 & 16,3 & 0,05 & 41,45 & 0,4 & 23,4 \\
\hline 2004 & 21,2 & 17,6 & 0,05 & 45,57 & 0,4 & 24,4 \\
\hline 2005 & 26,4 & 24,7 & 0,07 & 67,61 & 0,7 & 29,2 \\
\hline 2006 & 23,0 & 23,4 & 0,07 & 62,04 & 0,6 & 25,5 \\
\hline 2007 & 10,5 & 9,3 & 0,03 & 16,39 & 0,2 & 13,4 \\
\hline 2008 & 16,7 & 16,2 & 0,05 & 38,45 & 0,4 & 19,3 \\
\hline 2009 & 14 & 13,5 & 0,04 & 9,41 & 0,3 & 16,7 \\
\hline 2010 & 9,9 & 9,4 & 0,03 & 15,77 & 0,2 & 12,7 \\
\hline 2011 & 23,4 & 24,2 & 0,07 & 64,42 & 0,6 & 25,9 \\
\hline 2012 & 18,9 & 26,0 & 0,07 & 69,19 & 0,7 & 25,7 \\
\hline Średnia & 18,9 & 18,1 & 0,05 & 45,03 & 0,4 & 21,6 \\
\hline $\begin{array}{c}\text { Według } \\
\text { Bergela }[2,3,4] \\
\end{array}$ & 21,4 & 30,4 & 0,146 & 154,1 & 1,9 & 24 \\
\hline
\end{tabular}

wynika, iż wartości strat wody w analizowanym okresie mieszczą się w przedziale od $10 \%$ w roku 2010 do $26,4 \%$ w 2005 r. w stosunku do objętości wody wtłoczonej do sieci.

Analizując wskaźniki strat wody obliczone na podstawie bilansów wody (Tabela 3) można zauważyć, iż w rozpatrywanym wodociągu grupowym występują stosukowo nieduże wartości wskaźników strat wody. Wszystkie wskaźniki poza procentowym wskaźnikiem strat wody i wskaźnikiem objętości wody niedochodowej są mniejsze od średnich obliczonych przez Bergela [2,3,4] dla 67 wodociągów obsługujących $10000 \div 20000$ mieszkańców.

W latach 2005, 2006, 2011 i 2012 wartość procentowego wskaźnika strat wody przekraczała wartość literaturową równą $21,4 \%$. Średnia wartość $S$ dla okresu 2003-2012 równa 18,9\% jest mniejsza o 2,5\% od wartości literaturowej. Badany wodociąg charakteryzuje się dość wysokim poziomem wskaźnika objętości wody niedochodowej NRWB w latach 2004-2006 i 2011-2012 przekraczającym wartość literaturową równą 24\% nawet o 5,2\% w roku 2005.

Dla badanego wodociągu wartość wskaźnika nieuniknionych strat rzeczywistych $U A R L$ w 2012 r. wyniosła $527727,1 \mathrm{dm}^{3} / \mathrm{d}\left(192620,4 \mathrm{~m}^{3} /\right.$ rok $)$, co stanowiło aż $27 \%$ ilości wody wtłoczonej do sieci. We wcześniejszych latach wartość UARL była wyższa - w 2003 r. sięgała 38\% ilości wody wtłoczonej do sieci. Tak duże wartości wskaźnika nieuniknionych strat rzeczywistych powodują, że przedstawiona w tabeli 3 wartość wskaźnika ILI jest bardzo mała - wartość średnia $(0,4)$ jest mniejsza o 1,5 od danych literaturowych równych 1,9. Zgodnie ze standardami IWA, WBI Banding System dla krajów rozwiniętych i rozwijają- 
cych się oraz kryteriów przyjętych przez Amerykańskie Stowarzyszenie Wodne (AWWA) wartość $I L I \leq 1,5$ wskazuje na bardzo dobry stan techniczny sieci dystrybucji wody $[15,16]$. Należy podkreślić, że w warunkach rozpatrywanego wodociągu grupowego tak niska wartość wskaźnika ILI budzi wątpliwości.

\section{Bilans i analiza strat wody $w$ poszczególnych strefach zasila- nia w roku 2012}

Aby osiągnąc dokładniejszy obraz stanu rozpatrywanego wodociągu grupowego, ze względu na zróżnicowanie stref zasilania, dokonano analizy ilości wody wyprodukowanej i zużytej oddzielnie w każdej z czterech stref zasilania w 2012 roku. Podobnie jak przy analizie całego wodociągu, przeprowadzono bilans start wody metodą zalecaną przez IWA oraz analizę wskaźnikową. Działania te mają na celu wytypowanie strefy, w której występują największe straty wody.

W tabeli 4 przedstawiono objętość wody wyprodukowanej i sprzedanej w poszczególnych strefach zasilania w roku 2012. Największy udział zarówno w produkcji jak i w sprzedaży wody miała strefa $D$, najmniejszy strefa $C$ (prawie 3 krotnie mniejsza produkcja i sprzedaż wody).

Tabela 4. Objętość wody wyprodukowanej i sprzedanej w poszczególnych strefach zasilania w roku 2012

Table 4. The volume of water produced and sold in water supply zones in 2012

\begin{tabular}{|l|c|c|c|c|}
\hline \multicolumn{1}{|c|}{$\begin{array}{c}\text { Objętość wody } \\
{\left[\mathbf{m}^{3} / \mathbf{r o k}\right]}\end{array}$} & Strefa A & Strefa B & Strefa C & Strefa D \\
\hline Pobranej ze środowiska & 98880 & 210680 & 99500 & 291980 \\
\hline Sprzedanej & 73344 & 146901 & 74975 & 225535 \\
\hline
\end{tabular}

Wybrane wyniki bilansu wody z podziałem na strefy zasilania dla roku 2012 przedstawiono w tabeli 5.

Analiza wartości wskaźników strat wody przedstawionych w tabeli 6 wskazuje, że strefa zasilana z ujęcia D charakteryzuje się zarówno najwyższą produkcją jak i sprzedażą wody, a także względnie niskim poziomem rzeczywistych strat wody. W poszczególnych strefach największe różnice występują w przypadku wartości wskaźnika jednostkowych strat wody. Wartość $R L B$ dla strefy zasilanej z ujęcia D jest niemal 2-krotnie większa od wartości obliczonej dla ujęcia B i 3-krotnie mniejsza od danych obliczonych przez Bergela $[2,3,4]$ dla podobnych sieci $\left(154,1 \mathrm{dm}^{3} /(\right.$ szt. przył. d)). Również wartość wskaźnika $N R W B$ dla strefy zasilanej $\mathrm{z}$ ujęcia $\mathrm{D}$ wypada najkorzystniej na tle pozostałych trzech stref i jako jedyna nie przekracza ona wartości literaturowej równej $24 \%$. Wskaźnik ILI wyliczony dla czterech rozpatrywanych stref zasilania najmniejszą wartość przyjmuje w przypadku strefy zasilanej z ujęcia C, a największą dla 
Tabela 5. Składniki bilansu wody według metody IWA w strefach zasilania w roku 2012

Table 5. Components of water balance according to IWA standard in water supply zones in 2012

\begin{tabular}{|c|c|c|c|c|}
\hline $\begin{array}{c}\text { Składnik bilansu } \\
{\left[\mathrm{m}^{3} / \mathbf{r}\right]([\%])}\end{array}$ & Strefa A & Strefa B & Strefa C & Strefa D \\
\hline $\begin{array}{l}\text { Woda wtłoczona do } \\
\text { sieci }\end{array}$ & $98880(100 \%)$ & $210680(100 \%)$ & $99500(100 \%)$ & $291980(100 \%)$ \\
\hline $\begin{array}{l}\text { Autoryzowana kon- } \\
\text { sumpcja: } \\
\text { - zafakturowana } \\
\text { - niezafakturowana }\end{array}$ & $\begin{array}{c}73344(74,2 \%) \\
1450(1,5 \%) \\
\end{array}$ & $\begin{array}{c}146901(69,7 \%) \\
1950(0,9 \%) \\
\end{array}$ & $\begin{array}{r}74975(75,4 \%) \\
3500(3,5 \%) \\
\end{array}$ & $\begin{array}{c}225535(77,2 \%) \\
9510(3,3 \%) \\
\end{array}$ \\
\hline $\begin{array}{l}\text { Niezafakturowana } \\
\text { niezmierzona kon- } \\
\text { sumpcja: } \\
\text { • woda zużyta do } \\
\text { płukania sieci } \\
\text { - woda zużyta na } \\
\text { cele gospodarcze }\end{array}$ & $\begin{array}{l}450(0,004 \%) \\
1000(0,01 \%)\end{array}$ & $\begin{array}{l}500(0,002 \%) \\
1450(0,007 \%)\end{array}$ & $\begin{array}{l}2050(0,02 \%) \\
1450(0,01 \%)\end{array}$ & $\begin{array}{l}8060(0,03 \%) \\
1450(0,005 \%)\end{array}$ \\
\hline $\begin{array}{l}\text { Straty wody: } \\
\text { - pozorne } \\
\text { - rzeczywiste }\end{array}$ & $\begin{array}{c}4944(0,05 \%) \\
19142(19,4 \%)\end{array}$ & $\begin{array}{c}10534(5 \%) \\
512954,3 \%)\end{array}$ & $\begin{array}{c}4975(5 \%) \\
16050(16,1 \%)\end{array}$ & $\begin{array}{c}14599(5 \%) \\
42336(14,5 \%)\end{array}$ \\
\hline
\end{tabular}

Tabela 6. Wskaźniki strat wody w strefach zasilania w roku 2012

Table 6. Indicators of water losses in water intake zones in 2012

\begin{tabular}{|c|c|c|c|c|c|}
\hline Wskaźnik & Jednostka & Strefa A & Strefa B & Strefa C & Strefa D \\
\hline $\boldsymbol{O}_{\boldsymbol{s}}$ & {$\left[\mathrm{m}^{3} /(\mathrm{d} \cdot \mathrm{km})\right]$} & 16,45 & 5,63 & 5,68 & 9,17 \\
\hline $\boldsymbol{S}$ & {$[\%]$} & 24,4 & 29,3 & 21,1 & 19,5 \\
\hline $\boldsymbol{q}_{\boldsymbol{S} \boldsymbol{T} \boldsymbol{R}}$ & {$\left[\mathrm{dm}^{3} /(\mathrm{os} \cdot \mathrm{d})\right]$} & 29,9 & 43,4 & 21,2 & 18,5 \\
\hline $\boldsymbol{q}_{\boldsymbol{s} j}$ & {$\left[\mathrm{~m}^{3} /(\mathrm{h} \cdot \mathrm{km})\right]$} & 0,17 & 0,07 & 0,05 & 0,07 \\
\hline $\boldsymbol{R} \boldsymbol{L B}$ & {$\left[\mathrm{dm}^{3} /(\mathrm{szt} \cdot \mathrm{przy} \cdot \mathrm{d})\right]$} & 87,4 & 90,4 & 59,7 & 52,5 \\
\hline $\boldsymbol{U A R \boldsymbol { R }}$ & {$\left[\mathrm{m}^{3} / \mathrm{rok}\right]$} & 15029,3 & 74278,0 & 34285,3 & 70103,1 \\
\hline $\boldsymbol{I L I}$ & {$[-]$} & 1,3 & 0,7 & 0,5 & 0,6 \\
\hline $\boldsymbol{N R \boldsymbol { R } \boldsymbol { B }}$ & {$[\%]$} & 25,8 & 30,3 & 24,6 & 22,8 \\
\hline
\end{tabular}

strefy zasilanej z ujęcia A. Obliczone dla poszczególnych stref wartości $I L I \leq 1,5$,według standardów IWA, WBI Banding System oraz AWWA świadczą o bardzo dobrym stanie technicznym rozpatrywanej sieci wodociągowej $[2,3,4,13]$.

W tabeli 7 przedstawiono literaturowe wartości wskaźników start wody dla wodociągów charakteryzujących się obciążeniem sieci zbliżonym do obciążenia poszczególnych stref analizowanego wodociągu [2,3,4,6,10]. 
Tabela 7. Wskaźniki start wody według danych literaturowych na podstawie $[2,3,4,6,10]$

Table 7 . Indicators of water losses according to literature data on the basis of $[2,3,4,6,10]$

\begin{tabular}{|c|c|c|c|c|}
\hline \multirow{2}{*}{ Wskaźnik } & \multirow{2}{*}{ Jednostka } & \multicolumn{3}{|c|}{ Wielkość obciążenia sieci [m³/(km·d)] } \\
\hline & & ok. 6 & ok. 9 & ok. 16,5 \\
\hline$S$ & {$[\%]$} & $12,6-29,5$ & $18,8-33,0$ & $21,4-36,0$ \\
\hline$q_{S T R}$ & {$\left[\mathrm{dm}^{3} /(\mathrm{os} \cdot \mathrm{d})\right]$} & $10,7-27,0$ & $21,3-45,6$ & $30,4-72,3$ \\
\hline $\boldsymbol{q}_{s j}$ & {$\left[\mathrm{~m}^{3} /(\mathrm{h} \cdot \mathrm{km})\right]$} & $0,05-0,07$ & $0,07-0,12$ & $0,146-0,25$ \\
\hline$R L B$ & {$\left[\mathrm{dm}^{3} /(\right.$ szt. $\cdot$ przył·d $\left.)\right]$} & $46,1-134$ & $107,9-188,7$ & 235,3 \\
\hline$I L I$ & {$[-]$} & 0,8 & 1,7 & $*$ \\
\hline$N R W B$ & {$[\%]$} & 31,7 & 34,3 & * \\
\hline
\end{tabular}

* brak danych literaturowych

Porównując wartości wskaźników strat wody z wartościami zaobserwowanymi w sieciach o zbliżonym obciążeniu, możemy zauważyć, iż wartości uzyskane $\mathrm{w}$ poszczególnych strefach zasilania rozpatrywanego wodociągu $\mathrm{w}$ większości przypadków są zbliżone do wartości wyznaczonych w innych wodociągach. Strefa zasilana z ujęcia B charakteryzuje się stosunkowo wysokim wskaźnikiem jednostkowej objętości strat przypadającej na jednego mieszkańca $\left(q_{S T R}=43,4 \mathrm{dm}^{3} /(\right.$ os $\left.\cdot \mathrm{d})\right)$ w porównaniu do innych systemów o zbliżonym współczynniku intensywności obciążenia sieci. W strefie C, wartość wskaźnika jednostkowych strat rzeczywistych $R L B$ jest prawie 2-krotnie niższa niż w podobnych wodociągach. IWA zaleca, by stosować wskaźnik ILI tylko wtedy, gdy liczba przyłączy jest większa niż 5000, a ich gęstość przekracza 20 na km sieci wodociągowej oraz przy ciśnieniu w sieci co najmniej 0,25 MPa [12]. W badanej sieci spełniony jest jedynie warunek dotyczący ciśnienia.

\section{Podsumowanie i wnioski}

Przeprowadzony bilans oraz analiza strat wody wykazały, iż w rozpatrywanym wodociągu grupowym występują stosukowo nieduże wartości wskaźników strat wody. Najwyższą wartość wskaźnika strat wody zaobserwowano w 2005 roku (26,4\%), później nastąpił spadek do $9,9 \%$ w 2010 roku i ponowny wzrost. Niska wartość $I L I$, we wszystkich strefach poniżej 1,5 świadczy o bardzo dobrym stanie technicznym sieci, jednakże w przypadku analizowanej sieci parametr ten może nie być miarodajny ze względu na spełnienie tylko jednego z trzech zalecanych kryteriów jego stosowania. O poprawności działań eksploatacyjnych prowadzonych w badanej sieci świadczy prawie trzykrotnie niższa od wartości literaturowych, podawanych m.in. przez Bergela $[2,3,4]$ wartość wskaźnika strat jednostkowych $q_{s i}$. Wartość średnia dla okresu 2003-2012 wynosiła $0,05 \mathrm{~m}^{3} /(\mathrm{h} \cdot \mathrm{km})$. Straty wody w poszczególnych strefach są na porównywalnym poziomie od $19,5 \%$ w strefie D do $29,3 \%$ w strefie B. Porównując czte- 
ry strefy, w strefie B zaobserwowano najwyższą wartość wskaźnika jednostkowych strat rzeczywistych $\left(R L B=90,4 \mathrm{dm}^{3} /\right.$ (szt. przył. d)) oraz wskaźnika objętości wody niedochodowej $(N R W B=30,3 \%)$, co powinno stanowić sygnał dla eksploatatora, by na tę część wodociągu zwrócić szczególną uwagę przy podejmowaniu czynności zmierzających do ograniczenia strat wody.

\section{Literatura}

[1] Bauer A., Dietze G., Mueler W., Soine K.J.: Weideling, D. Poradnik eksploatatora systemów zaopatrzenia w wodę. Seidel-Przywecki, Warszawa 2005.

[2] Bergel T.: Analiza wskaźnikowa start wody w sieci wodociągowej w gminach wiejskich i miejsko-wiejskich w Polsce (cz.1), Gaz, Woda i Technika Sanitarna 8, 2012, s. 322-325.

[3] Bergel T.: Analiza wskaźnikowa start wody w sieci wodociągowej w gminach wiejskich i miejsko-wiejskich w Polsce (cz.2), Gaz, Woda i Technika Sanitarna 10, 2012, s. 413-415.

[4] Bergel T.: Skala i powody marnotrawstwa wody w wodociągach wiejskich, Gaz, Woda i Technika Sanitarna 9, 2009, s. 30-32.

[5] Boryczko K., Tchórzewska-Cieślak B.: Analiza eksploatacji sieci wodociągowej miasta Mielca, w Polska inżynieria środowiskowa pięć lat po wstąpieniu do Unii Europejskiej (red. J.Ozonek, A.Pawłowski) t.58/1, 2009, s. 27-33.

[6] Choma A., Iwanek M., Kowalska B., Kowalski D.: Analiza strat wody w sieci wodociągowej eksploatowanej przez Zakład Gospodarki komunalnej w Puchaczowie, Instal 10 (355), 2014, s. 61-65.

[7] Dohnalik P., Jędrzejowski Z.: Efektywna eksploatacja wodociągów. Ograniczanie strat wody, LemTech, Kraków 2004.

[8] Farley M., Trow S.: Losses in Water Distribution Networks. A Practitioner's Guide to Assessment, Monitoring and Control. IWA Publishing, 2003.

[9] Hotloś, H.: Analiza strat wody w systemach wodociągowych. Ochrona Środowiska 25 (1), 2003, s. 17-24.

[10] Iwanek M., Musz A., Kowalska B., Kowalski D., Chołody M.: Analiza strat wody w wybranym wodociaggu grupowym, Instal 1(369), 2016, s. 40-43.

[11] Kowalski D., Kowalska B., Kwietniew ski M., Sygacz-Adamska J.: Analiza bilansu wody oraz awaryjności wybranego system dystrybucji wody w: Zaopatrzenie w wodę, jakość i ochrona wód, tom II (Dymaczewski Z., Jeż-Walkowiak J., Red.). Poznań: PZITS Oddział Wielkopolski, 2012, s.77-92.

[12] Kwietniewski M.: Zastosowanie wskaźników strat wody do oceny efektywności jej dystrybucji w systemach wodociągowych, Ochrona Środowiska 4(35), 2013, 9-16.

[13] Lambert A., Hirner W.: Losses from water supply systems. Standard terminology and recommended performance measures, IWA Blue Pages 2000.

[14] Merlo G.: Straty wody, wykrywanie i ocena. Wodomierze w komunalnych systemach wodociągowych, IWSA Workshop, Warszawa 1992.

[15] Piechurski F.: Działania zmierzające do ograniczenia strat wody w systemach jej dystrybucji. Napędy i sterowanie, $\mathrm{nr}$ 1, 2014, s 68-79. 
[16] Rak J., Sypień Ł.: Analiza strat wody w wodociągu miasta Jasło, Czasopismo Inżynierii Lądowej, Środowiska i Architektury t.XXX , 60(3), 2013, s,. 5-18. DOI: 10.7862/rb.2013.33.

[17] Siwoń Z., Cieżak J., Cieżak W.: Praktyczne aspekty badań strat wody w sieciach wodociągowych, Ochrona Środowiska 26 (4), 2004, s. 25-30.

[18] Tchórzewska-Cieślak B., Szpak D.: Zarządzanie miejską infrastrukturą wodociągową, Czasopismo Inżynierii Lądowej, Środowiska i Architektury t. XXXI, z. 61 (1/14), 2014, s. 343-355, DOI:10.7862/Rb.2014.24.

[19] Zimoch I., Szymura E.: Klasyfikacja stref systemu dystrybucji wody według wskaźników strat wody i awaryjności sieci, Instal nr 7-8, 2013, s. 64-68.

[20] Żaba T., Langer A.: Monitoring strat wody elementem ograniczenia kosztów działalności przedsiębiorstwa. Napędy i Sterowanie 4, 2012, s. 100-103.

\section{ANALYSIS OF WATER LOSSES IN A SELECTED WATER SUPPLY SYSTEM}

\section{S u m m a r y}

The aim of the article is analysis of the selected water supply system operation in the years 2003-2012 with regard to water losses. The investigated system consists of four adjoining water intake zones (A, B, C, D). The total length of pipes including connections equals $489 \mathrm{~km}$. The network is made of PVC-U and PE-HD pipes mainly. Water intensity indicator values are different in respective zones - from $5.63 \mathrm{~m}^{3} /(\mathrm{d} \cdot \mathrm{km})$ in the zone B to $16.45 \mathrm{~m}^{3} /(\mathrm{d} \cdot \mathrm{km})$ in the zone A. In the period of 2003-2012 the average water volume of $598794.2 \mathrm{~m}^{3} / \mathrm{yr}$ was produced.

Investigations were conducted using the standard International Water Association (IWA) balance and indicators methods. Percentile water losses index $(S)$, unit water losses volume per person $\left(q_{S T R}\right)$, unit index of water losses $\left(q_{s j}\right)$, real losses level for system with density of connections greater than 20 per $\mathrm{km}$ of mains $(R L B)$, infrastructure leakage index $(I L I)$ and non-revenue water basic $(N R W B)$ were calculated. Investigations were conducted on the basis of data obtained from the water corporation.

The highest value of the most analyzed indicators was observed in 2005. After this year the values of the indicators were lower and increased again in 2010 . $I L I<1.5$ for each zone indicates very good technical condition of the network. The greatest losses were observed in the B zone. All the obtained indicators appeared to be comparable with literature data for similar water systems.

Keywords: water losses indicators, water balance, IWA method

Przestano do redakcji: $30.08 .2015 \mathrm{r}$.

Przyjęto do druku: 1.03.2016 r.

DOI: $10.7862 / \mathrm{rb} .2016 .120$ 
